\title{
INOVAÇÃO: EFEITOS INESPERADOS, INTERAÇÕES E COMPLEXIDADE
}

Recentemente, Steve Johnson discutiu em um texto extremamente interessante, como chegamos ao "agora", selecionando seis inovações que, em sua opinião, fizeram o mundo moderno [1]: o vidro, a refrigeração, o som e sua gravação, o saneamento e a purificação de água, a medida do tempo, e a iluminação artificial. Johnson discute, em diversos casos, os efeitos inesperados das invenções. Um exemplo interessante é a demanda por lentes, lentes corretivas e óculos, decorrente da invenção da imprensa por Gutemberg: miopia e outras dificuldades de visão, em muitos casos sequer percebidos, tornaram-se, com a disseminação do livro, problema importante e geraram um conjunto de invenções e desenvolvimento que culminaram com as invenções do telescópio e do microscópio. Estas invenções que, como Johnson discute, tiveram profundo poder de afetar dramaticamente como, quanto e onde vivemos, são, do ponto de vista técnico e científico, acessíveis à compreensão de alguém com educação superior na área tecnológica, e podem ser explicadas, de forma simplificada, a pessoas com uma educação média razoável. Assim foi com grande parte das inovações e tecnologias desenvolvidas até, aproximadamente, a metade do século $X X$.

O final do século $X X$, entretanto, assistiu a um período em que a interação entre diferentes áreas do conhecimento em busca da inovação se tornou um método de trabalho formidável. Com esta multidisciplinaridade veio, naturalmente, uma complexidade admirável das tecnologias que nos cercam. Se éramos capazes de explicar a jovens os fenômenos responsáveis pela iluminação incandescente ou até mesmo fluorescente, é difícil imaginar uma explicação simples e acessível para um LED. Diante da combinação de tecnologias em um telefone celular, então, o desafio é praticamente intransponível. Da mesma forma, até as últimas décadas do século $X X$, os automóveis eram de tamanha simplicidade tecnológica que proliferavam as oficinas de reparo e os proprietários mais interessados eram capazes de realizar manutenções, ao menos nos níveis mais simples. Do final do século XX em diante, a complexidade dos automóveis exige apoio da informática e de tecnologias sofisticadas para diagnóstico e reparo. Se, por um lado, este avanço vem permitindo benefícios incríveis de acesso cada vez mais universalizado, e tornando a vida mais confortável para muitos, por outro lado dificulta cada vez mais a compreensão dos princípios de funcionamento das coisas que nos cercam. Como as carreiras tecnológicas, especialmente a engenharia, são responsáveis por concretizar ideias, transformando conceitos em produtos, vale a pena discutir até que ponto esta enorme complexidade pode agir como agente desmotivante para o ingresso dos jovens nestas profissões. Enquanto no século passado a curiosidade dos potenciais candidatos a estas carreiras era satisfeita por explicações acessíveis e até pela aventura da desmontagem exploratória ou da manutenção "não-qualificada", é difícil imaginar a possibilidade destas "aventuras" com os produtos do dia de hoje. Até que ponto a falta destas experiências tem tido impacto na escolha por carreiras tecnológicas? Será preciso substituir esta experiência motivadora por outros tipos de interações, aproveitando as técnicas hoje disponíveis?

André Luiz Vasconcellos da Costa e Silva Editor-Chefe

\section{REFERÊNCIAS}

I Johnson S. How we got to now: six innovations that made the modern world. New York: Riverhead Books; 20 I4. 